\title{
DEVELOPMENT OF HIGH STRENGTH SELF CONSOLIDATING CONCRETE CONTAINING FLY ASH AND GGBS
}

\author{
T. Nikhil Singh ${ }^{1}$ B. Narendra Kumar ${ }^{2}$ \\ ${ }^{I}$ PG Student Structural Engg, Department of Civil Engineering, VNR VJIET, Bachupally, Hyderabad, India \\ ${ }^{2}$ Professor, Department of Civil Engineering, VNR VJIET, Bachupally, Hyderabad, India
}

\begin{abstract}
Self-consolidating/compacting concrete (SCC) is used in a wide range forpurpose of construction of high raised buildings, pavements and industrial applications which may be suitable to a highrange of temperatures to support fire resistance. The meaning of standard temperatures on the properties of self-compacting concrete is necessary. This presents the reports of laboratory experimental investigations carried out in order to study on the development of High performance and high Strength Self Consolidating Concrete containing/using GGBS, fly ash, and cement as a binder and its effect on the compressive strength of concrete at standard water-cement ratio in self-compacting concrete. It is found that the compressive strength of self-compacting concrete decreases with increasing in temperature. It is compared with normal-strength self-compacting concrete to possess a larger amount of compressive strength of concrete which is exposed to high strength temperature. In the experiment, flyash was varied by $5 \%, 15 \%, 25 \%$, and 35\%. GGBS was kept constant at 20\% for all mixes. Cement was proportioned as $75 \%$, 65\%, 55\%, and $45 \%$ respectively. The mechanical properties of the self compacting concrete are Compressive strength, Split Tensile Strength, and Flexural properties were examined by replacing VMA with conplast 430.
\end{abstract}

Keywords: - self-compacting,conplast SP430, Fly Ash, GGBS, Cement.

\section{INTRODUCTION}

The requirement of self compacting concrete is increased from last 10 to 15 years because of which the requirement of labor for the work proposed has been decreased. The self compacting concrete is used for the process of fast construction works and to complete the work on time. The advantage of self compacting concrete is to develop fast in construction work and save time and money. The requirement of labor is also very less. In self compacting there is no required of vibration and compaction process after the mix and it can be easily mixed and placed. it is durable and it is a thinner concrete section which makes less noise and environmental friendly. The standard of construction of concrete are important in order to have a durable concrete constructed structure and one of the main reasons to make a durable concrete constructed structure is in the process of proper compaction of structure which requires working men but due to shortage of working men for the proper compaction and vibration cannot be done which is shown in Fig 1. For which we have to use self compacting concrete which does not required compaction and vibration. The resolvance to this process is to use the self-compacting concrete with compaction in every depth of working/built area.

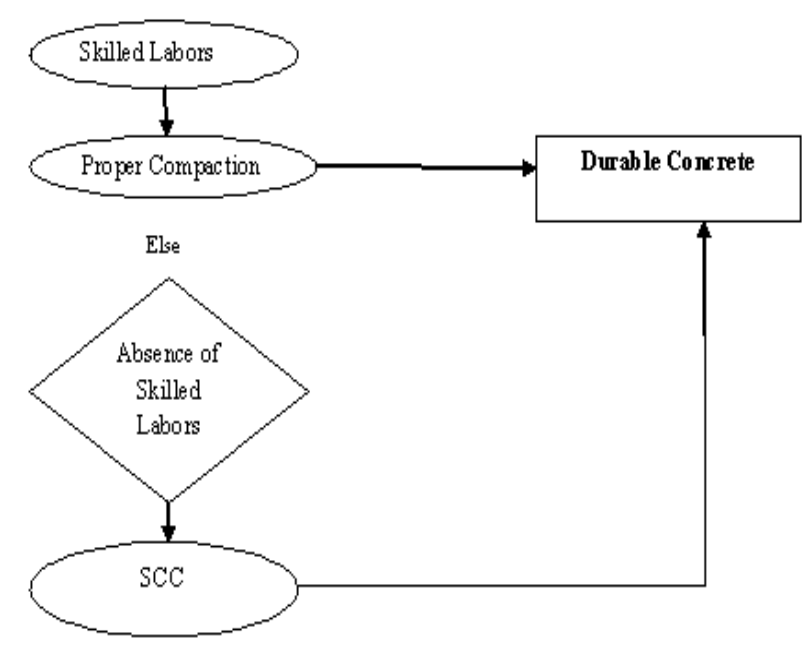

Fig 1: Details of work program

\section{LITERATURE REVIEW}

Biswadeep Bharali has analyzed that the addition of GGBS and FA as mineral additives in self-compacting concrete is a step that the strength properties are higher from 7 days to 28 days

S.SARANYA have concluded that Fresh concrete properties such as flow test, L box test, and V funnel test show good flowing ability, segregation resistance with replacement in cement with mineral admixtures such as fly ash and GGBS at right proportions. 
G. Pavan Kumar, N.R. Gowthami, Naresh Kumar have concluded that based on the evaluation examined for the study of the behavior of self-compacting concrete using ggbs and fly ash the following conclusions made to check the workability tests on filling ability tests, flowing ability tests and segregation tests. The Young's Modulus test results for various alternative levels of fly ash and GGBS by Cement such as normal concrete and variation of $0 \%, 5 \%$, $15 \% \& 20 \%$ percentages of fly ash in self-compacting concrete consider at 28-days strength.

Aijaz Ahmad Zende, Dr. R. B. Khadirnaikar have analyzed the using of Self-compacting concrete for development in construction is not much increased because lack of knowledge about self compacting concrete. While in Canada apart from Japan, self-compacting concrete is used for the use of development of construction and from research Data available, awareness about self compacting concrete can be spread in order to utilize the various benefits from self compacting concrete.

M. Vimalanathan has concluded that various curing period 7, 14 and 28 days compressive strength increase high compared to the normal cube. Self-compacting concrete technology can save time, cost, and durability.

\section{MATERIALS AND MIX PROPORTIONS}

The general ingredients required for development of high strength high performance self-compacting concrete are fly ash, ggbs,cement, fine aggregate, coarse aggregate and super plasticizer and it uses more powdered contents and less coarse aggregates in addition to reduce water quantity in a larger amount. In this mix we haven't used viscosity modifying agent. The factors which dominate the selection of materials are-

i. A quantity of aggregates used in self compacting concrete which are different from ideological shapes and sizes.

ii. Type of superplasticizer used.

iii. Types of powder used (fly ash and ggbs).

iv. Compatibility between cement, water, superplasticizer, flyash,andggbs.

\subsection{Cement}

In the present work for self compacting concrete we have used ordinary Portland cement of grade 53 of ultra tech super cement conforming with IS 12269:1987. The properties of the cement used are shown in TABLE 1.

Table 1: Properties of cement

\begin{tabular}{|l|l|}
\hline Physical Properties & Results \\
\hline $\begin{array}{l}\text { Fineness by dry sieve \% } \\
\text { (90 microns) }\end{array}$ & $5 \%$ \\
\hline Specific Gravity & 3.1 \\
\hline Initial setting time (min) & 205 \\
\hline Final setting time (min) & 317 \\
\hline Normal Consistency & $31 \%$ \\
\hline Compressive strength at & 35.20 \\
\hline
\end{tabular}

\begin{tabular}{|l|l|}
\hline 3- days (N/mm2) & \\
\hline $\begin{array}{l}\text { Compressive strength at } \\
\text { 7- days (N/mm2) }\end{array}$ & 47.50 \\
\hline $\begin{array}{l}\text { Compressive strength at } \\
\text { 28- days (N/mm2) }\end{array}$ & 54.26 \\
\hline
\end{tabular}

\subsection{Aggregates}

The shape and size of aggregates plays an important role in producing a self-compacting concrete. Naturally collected aggregates have been used as the coarse aggregates in the following self compacting concrete mixtures. crushed material of medium size of $20 \mathrm{~mm}$ were used as the natural coarse aggregate.

Table 2: Properties of Coarse Aggregates

\begin{tabular}{|l|l|}
\hline Property & Value \\
\hline Size & $20 \mathrm{~mm}$ \\
\hline Shape & Irregular \\
\hline Specific gravity & 2.71 \\
\hline Abrasion & $27.58 \%$ \\
\hline Water Absorption & $0.50 \%$ \\
\hline Crushing value & $14.22 \%$ \\
\hline
\end{tabular}

Low gradation of aggregates causes the affect of flow ability in self-compacting concrete. Because of shortage of sand in present days due to the environmental impact of mining of rivers by extracting sand from it, but we have used fine aggregates for the production of self-compacting concrete.

\subsection{Superplasticizers}

High ranged water reduced admixture plays an unique role in the process of required flow at the stage of low water contents. In this experiment, we have used conplast sp 430 as superplasticizer.

\subsection{Fly Ash}

Fly ash is residue obtained after combustion of coal. Fly ash is used in the study from ASTM Class F and we have bought it from the redimix plant near Bachupally in Hyderabad. The specific gravity of fly ash is 1.79 and it is $F$ Class fly ashes. It is produced from sub-bituminous and bituminous coals and it contains silicates and alumina which are used as the active components. In this experimental work, fly ash is taken as a binder.

\subsection{Ground Granulated Blast Furnace Slag (GGBS)}

Ground granulates Blast furnace slag is a by-product obtained in the manufacture of iron. It is a product formed by the combination of the earthy constituents of iron-ore with the limestone flux at high temperature in the blast furnace (about 1500 0c). The specific gravity of GGBS is 2.58. In this experimental we have used GGBS as a binder. 
Table 3: Properties of Fly Ash and GGBS

\begin{tabular}{|l|l|l|}
\hline Property & Fly-ash & GGBS \\
\hline Specific gravity & 1.79 & 2.58 \\
\hline $\begin{array}{l}\text { Bulk density } \\
\left(\mathrm{Kg} / \mathrm{m}^{3}\right)\end{array}$ & $500-800$ & 1100 \\
\hline Appearance & Grey & White \\
\hline Particle size & 30 microns & 25 microns \\
\hline Fineness $\left(\mathrm{m}^{2} / \mathrm{kg}\right)$ & 350 & 380 \\
\hline
\end{tabular}

\subsection{Super Plasticizer (Conplast sp 430)}

Conplast sp 430 is an admixture of a new modern age based on polycarboxylic ether. The material has been primarily evolve in High-performance and high strength self compaction concrete where it is highly durable and performance is required. Super plasticizer (Conplast 430) is free of chlorine and it is low in alkali. It is compatible for all types of cement. The product complies with ASTM C494 Type F.

Table 4: Properties of conplast 430

\begin{tabular}{|l|l|}
\hline Aspect & $\begin{array}{l}\text { brownishfree-flowing } \\
\text { liquid }\end{array}$ \\
\hline Relative Density & $1.08,0.01$ at $25^{\circ} \mathrm{C}$ \\
\hline PH 7 & \pm 1 \\
\hline Chlorine iron content & $<0.2 \%$ \\
\hline
\end{tabular}

\section{RESULTS \& DISCUSSION}

\subsection{Compressive Strength}

Compressive strength of self compacting concrete has the tendency to resist structural loads and it is evaluated from the breaking strength of cube. The Cubes size is $150 \mathrm{~mm} \mathrm{X}$ $150 \mathrm{~mm}$ X150 mm the volume of the cube is $0.003375 \mathrm{~m}^{\wedge} 3$

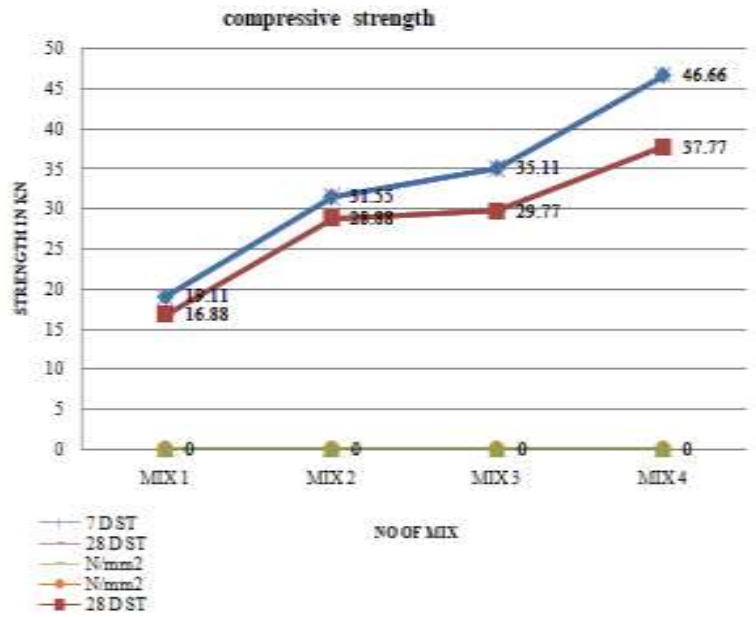

Fig 2: Compressive Strength

\subsection{Split Tensile Strength}

The split tensile strength of self-compacting concrete is also an important property to cast cylinders are used to determine the tensile strength of self-compacting concrete. Cylinders of size $150 \mathrm{~mm}$ diameters and $300 \mathrm{~mm}$ length are cast and tested.

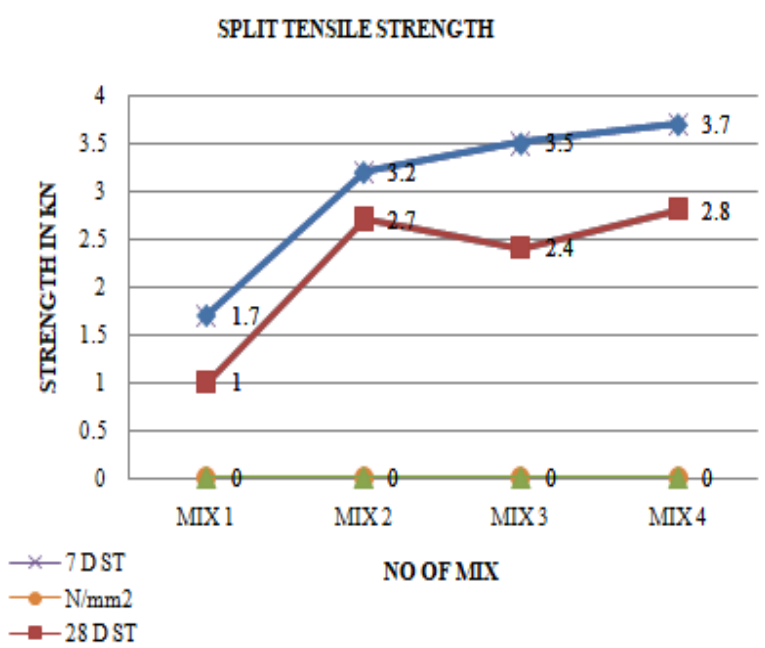

Fig 3: Split Tensile Strength

\subsection{Flexural Strength}

Flexural strength is calculated from the bending strength of block made with concrete material. It is a concrete beam or slab to resist bending of block. It is measured by area of beam $(100 \times 100 \times 500 \mathrm{~mm})$ the volume of beam that is $0.005 \mathrm{~m} 3$.

\section{FLEXURAL STRENGTH}

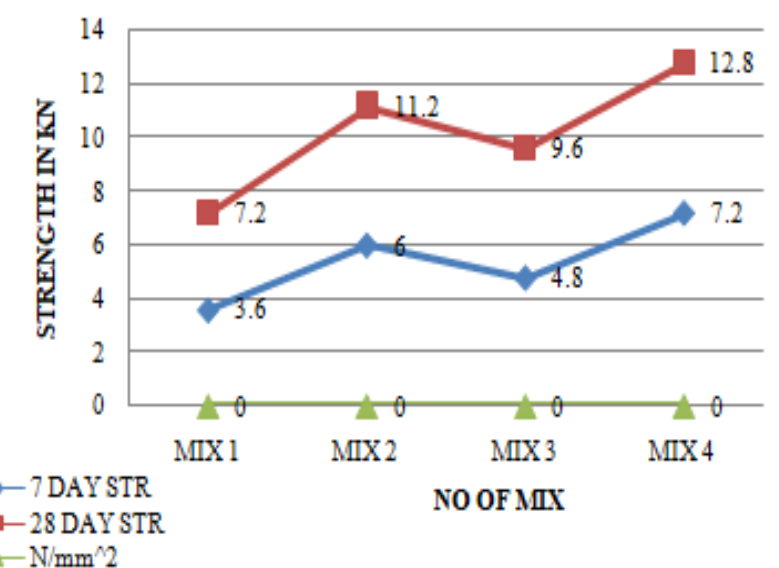

Fig 4: Flexural Strength 
Table 5: Experimental Program

\begin{tabular}{|c|c|c|c|c|c|c|c|}
\hline $\begin{array}{l}\text { Mix } \\
\text { Designation }\end{array}$ & $\begin{array}{l}\text { cement } \\
\text { in } \\
\left(\mathrm{kg} / \mathrm{m}^{3}\right)\end{array}$ & $\begin{array}{l}\text { GGBS } \\
\text { in } \\
(\mathrm{kg} / \mathrm{m} 3)\end{array}$ & $\begin{array}{l}\text { Fly Ash } \\
\text { in } \\
\left(\mathrm{kg} / \mathbf{m}^{3}\right)\end{array}$ & $\begin{array}{l}\text { Coarse } \\
\text { aggregate(C.A) } \\
\text { in }\left(\mathbf{k g} / \mathbf{m}^{3}\right)\end{array}$ & $\begin{array}{l}\text { Fine } \\
\text { aggregate(F.A) } \\
\text { in }\left(\mathbf{k g} / \mathbf{m}^{3}\right)\end{array}$ & $\begin{array}{l}\text { SP \% of } \\
\text { powder } \\
\text { content }\end{array}$ & $\begin{array}{l}\text { Extra } \\
\text { water }\end{array}$ \\
\hline MIX 1 & 410 & $20 \%$ & $5 \%$ & 1020 & 1210 & 1.2 & $23 \%$ \\
\hline MIX 2 & 360 & $20 \%$ & $15 \%$ & 1020 & 1210 & 1.2 & $23 \%$ \\
\hline MIX 3 & 300 & $20 \%$ & $25 \%$ & 1020 & 1210 & 1.2 & $23 \%$ \\
\hline MIX 4 & 250 & $20 \%$ & $35 \%$ & 1020 & 1210 & 1.2 & $23 \%$ \\
\hline
\end{tabular}

\subsection{Rheological Properties}

Rheological values from slump flow table tests, V-funnel tests, and L- box tests which are performing according to EFNRC guidelines which are mentioned below in table no 6.

Table 6: slump flow test, V-funnel test, and L- box test values are mentioned below

\begin{tabular}{|c|c|c|c|c|}
\hline \multirow[b]{2}{*}{ Mixing } & \multicolumn{2}{|c|}{ Slump Flow Table } & \multirow{2}{*}{$\begin{array}{l}\text { V Funnel } \\
T_{\mathrm{f}}(\mathrm{sec})\end{array}$} & \multirow[b]{2}{*}{ L- box } \\
\hline & $\begin{array}{l}\mathbf{T}_{50} \\
(\mathbf{s e c})\end{array}$ & $\begin{array}{l}\text { Diameter } \\
(\mathrm{mm})\end{array}$ & & \\
\hline $\begin{array}{l}\text { SELF COMPACTING } \\
\text { CONCRETE } 1\end{array}$ & 5 & 650 & 10 & 0.88 \\
\hline $\begin{array}{l}\text { SELF COMPACTING } \\
\text { CONCRETE } 2\end{array}$ & 3 & 680 & 8 & 0.85 \\
\hline $\begin{array}{l}\text { SELF COMPACTING } \\
\text { CONCRETE } 3\end{array}$ & 4 & 630 & 7 & 0.83 \\
\hline $\begin{array}{l}\text { SELF COMPACTING } \\
\text { CONCRETE } 4\end{array}$ & 3 & 690 & 12 & 0.90 \\
\hline
\end{tabular}

\section{Compressive Strength}

$>\quad$ The compressive strength value for the mix 1 is 16.88 $\mathrm{N} / \mathrm{mm} 2$ for 7 days strength and for 28 days it is 19.11 $\mathrm{N} / \mathrm{mm} 2$.

$>\quad$ The compressive strength value for the mix 2 is 21.88 $\mathrm{N} / \mathrm{mm} 2$ for 7 days strength and for 28 days it is 31.55 $\mathrm{N} / \mathrm{mm} 2$.

$>$ The compressive strength value for the mix 3 is $29.77 \mathrm{~N} / \mathrm{mm} 2$ for 7 days strength and for 28 days it is $35.11 \mathrm{~N} / \mathrm{mm} 2$.

$>\quad$ The strength value for the mix 4 is $37.77 \mathrm{~N} / \mathrm{mm} 2$ for 7 days strength and for 28 days it is $46.66 \mathrm{~N} / \mathrm{mm} 2$.

$>$ It is absorbed that the compressive strength from 7 days to 28 days is increasing rapidly.

\section{Split Tensile Strength}

$>\quad$ The split tensile strength for $1^{\text {st }}$ mix is $1 \mathrm{~N} / \mathrm{mm} 2$ for 7 days strength and for 28 days it is $1.7 \mathrm{~N} / \mathrm{mm} 2$.

$>\quad$ The split tensile strength for $2^{\text {nd }} \operatorname{mix}$ is $2.7 \mathrm{~N} / \mathrm{mm} 2$ for 7 days strength and for 28 days it is $3.2 \mathrm{~N} / \mathrm{mm} 2$.

$>$ The split tensile strength for $3^{\text {rd }}$ mix is $2.4 \mathrm{~N} / \mathrm{mm} 2$ for 7 days strength and for 28 days it is $3.5 \mathrm{~N} / \mathrm{mm} 2$.
$>$ The split tensile strength for the $4^{\text {th }}$ mix is $2.8 \mathrm{~N} / \mathrm{mm} 2$ for 7 days strength and for 28 days it is $3.7 \mathrm{~N} / \mathrm{mm} 2$.

$>$ It is obtained that split tensile strength from 7 days to 28 days strength is increasing rapidly.

\section{Flexural Strength}

$>$ The Flexural strength value for the mix 1 is $3.6 \mathrm{~N} / \mathrm{mm} 2$ for 7 days strength and for 28 days it is $7.2 \mathrm{~N} / \mathrm{mm} 2$.

$>\quad$ The Flexural strength value for the mix 2 is $6 \mathrm{~N} / \mathrm{mm} 2$ for 7 days strength and for 28 days it is $11.2 \mathrm{~N} / \mathrm{mm} 2$.

$>$ The Flexural strength value for the mix 3 is $4.8 \mathrm{~N} / \mathrm{mm} 2$ for 7 days strength and for 28 days it is $9.6 \mathrm{~N} / \mathrm{mm} 2$.

$>$ The Flexural strength value for the mix 1 is $7.2 \mathrm{~N} / \mathrm{mm} 2$ for 7 days strength and for 28 days it is $12.8 \mathrm{~N} / \mathrm{mm} 2$.

$>$ It is absorbed that the strength from 7 days to 28 days flexural strength from $1^{\text {st }}$ mix to $2^{\text {nd }}$ mix but decrease in $3^{\text {rd }}$ mix and again increase in $4^{\text {th }}$ mix. 


\section{CONCLUSION}

- It is obsorbed that Increase of $20 \%$ compressive strength from 7 days to 28 days.

- It is observed that Increase of $40 \%$ split tensile strength from 7 days to 28 days.

- It is observed that Increase of $50 \%$ flexural strength from 7 days to 28 days flexural strength.

- Optimisation of mix also satisfies all the rheological properties from EFNRC guidelines.

\section{REFERENCES}

[1] An Overview of the Properties of Self Compacting Concrete. (Prof. Aijaz Ahmad Zende, Dr. R. B. Khadirnaikar, IOSR Journal of Mechanical and Civil Engineering (IOSR-JMCE) International Conference on Advances in Engineering \& Technology - 2014 (ICAET-2014))

[2] Experimental Study on Self Compacting Concrete (SSC) Using Ggbs and Fly (Biswadeep Bharali , International Journal Of Core Engineering \& Management (IJCEM) Volume 2, Issue 6, September 2015)

[3] Experimental Study on Self Compacting Concrete (SCC) Using Fly Ash and GGBS (S.SARANYA, International Journal of Scientific \& Engineering Research Volume 8, Issue 6, June-2017)

[4] Experimental Investigation on Mechanical Properties of Self Compacting Concrete by Partial Replacement of Fly Ash and GGBS (G. Pavan Kumar, N.R. Gothami , T. Naresh Kumar, Year, Journal Name) EFNARC, 2002.

[5] Experimental Study of Self Compaction Concrete Using Fly ash and GGBS (M. Vimalanathan1, Volume 5 Issue VI, June 2017, International Journal for Research in Applied Science \& Engineering Technology (IJRASET))

\section{REFERENCES}

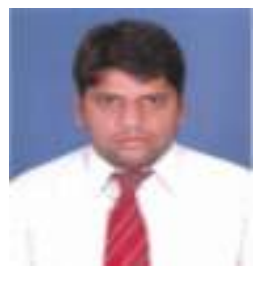

T.Nikhil Singh is currently pursuing Post-graduation (M.Tech.) in Structural Engineering at VNRVJIET, Hyderabad.

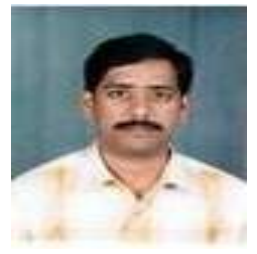

Dr. B. Narendra Kumar is currently working as Professor of Civil Engineering at VNRVJIET, Hyderabad. 